\title{
Endophyte Fungi to Control Helminthosporium turcicum, Fungi Causing Leaf Blight Disease
}

\author{
Ika Rochdjatun Sastrahidayat, Akhmat Riza Faizah, Anton Muhibuddin \\ Majoring in Pests and Plant Diseases, Agriculture Faculty of Brawijaya University \\ Correspondence Author : akhmatrizaf@gmail.com
}

\begin{abstract}
Leaf blight disease is one of the most dangerous diseases of maize plant. This disease be able causing loss of maize harvest up to $40-70 \%$. The cause of the leaf blight disease is Helminthosporium turcicum fungi. Biological control with endophytic fungi potentially used to control the pathogens as well as increase the resistance of plant induction to disease. Research was conducted in PT Bisi Inernational area, Tbk Farm Ngantang Malang Regency, Laboratory of Mycology Department of Plant Pest and Disease, Faculty of Agriculture Brawijaya University and Bioscience Laboratory Brawijaya University on December 2016 until July 2017. The exploration result of endophytic fungi of three varieties of maize were obtained 30 isolates, consisting of 14 non-pathogenic isolates and 16 pathogenic isolates. Based on the power inhibition percentage to the highest growth of H. turcicum is a fungi with NuII2, NuII4, PuIII3, DuIII3, NuII3 and PuIII1 isolates code. The most prevalent inhibition mechanism is pathogens and endophytic fungi competition. The 30 isolates identified were Colletotrichum sp, Fusarium sp, Curvularia sp, Acremonium sp dan Paecilomyces sp, meanwhile the other endophytic fungi is only found sterile hyphae thus difficult to identify up to the genus level.
\end{abstract}

Keywords : Endophyte fungi, Zea mays, Helminthosporium turcicum 


\section{Introduction}

In Indonesia, maize is an important food sources after rice. By the growing number of people, the need of maize is also increase, but not followed by the increasing of resulting in shortages production at any time of 1.3 million tons which must be fulfilled through imports. To fulfill the supply shortage of maize needs to be pursued through the increase production (Bakhri, 2007).

The national maize production during the last 5 years indicate an upward tendency of 11.609.403 tons (2006), 13.287.572 tons (2007), 15.860.299 tons (2008), 17.041.215 tons (2009) and 18.327.636 tons in 2010 (Statistics Central Bureau, 2012). During the 2010 to 2015 period, there were 2 decreases in maize production namely in 2011 the production of maize drop to $3.73 \%$ compared to the previous year to 17.643 million tons and in 2013 maize production drop to $4.51 \%$ compared to the previous year or reached up to 18.512 million tons.

In its growth, maize plant could not be separated from the various attacks of pest organism. A leaf blight is one of the most dangerous diseases of maize. This disease be able to result in the loss of maize harvest up to $40-70 \%$ (Ogliari et al., 2005) and at the high transmission rate the harvest loss could reach up to $100 \%$ (Roliyah, 2002).

One of the safe disease control alternative is biological control by using endophytic fungi which antagonistic to increase the resistance of plant induction to disease (Sudhantha and Abadi, 2006). Endophyte fungi is the microorganisms contained in plant host tissue without causing the disease symptoms for all or part of the life cycle (Petrini, 1992). There is a mutualistic interaction between endophytic microbes and host plants, each has benefit from the interaction (wilson, 1995).

The profound understanding of the endophyte fungi variety within the plant tissue and its antagonistic ability against pathogenic fungi needs to be more examined, in order to further known potential of the endophytic fungi as the biocontrol agents which be able to reduce the use of fungicides in disease control.

\section{Research methods}

The research was conducted in experimental area of PT Bisi Inernational, Tbk Farm Ngantang Malang Regency, Laboratory of Mycology Department of Plant Disease and Herbs Faculty of Agriculture Brawijaya University and Bioscience Laboratory of Brawijaya University on December 2016 until July 2017.

The tools were used namely scissors, paper envelopes, fridge, light microscopes, SEM (Scanning Electron Microscope) LAFC (Laminar Air Flow Cabinet), measuring cylinders, erlenmayer tubes, hot plate, autoclave, analytical scales, drop pipette, tweezers, bunsen, ose needle, petri dish, glass object, spray bottle, wraping, aluminum foil, stationery and camera.

The materials were used namely NK212 maize seed, Pertiwi 2, DK95, PDA medium (Potato Dextrose Agar), chlorox, $70 \%$ and $96 \%$ alcohol, metylenblue, ethanol with concentrations of $30 \%, 50 \%, 70 \%, 80 \%, 90 \%$ and $96 \%$, sterile aquades and tissue.

\section{Leaf Sampling}

Plant leaf sampling conducted once in the generative phase at 52 HST age. Leaf samples that taken from each variety were the asymptomatic healthy leaves from the leaf blight or other diseases. Maize crop varieties were categorized as the most resistant to the attack of leaf blight disease which as much as 3 varieties of maize.

\section{Endophyte Fungi Isolation}

Endophyte fungi Isolation is according to Muhibuddin et al. (2014) method, which conducted within the Laminar Air Flow Cabinet (LAFC). The equipment were used for the isolation namely scissors and tweezers that sterilized first with the $96 \%$ alcohol and heated above Bunsen approximately one minute.

Initial step of the isolation is maize crop leaves sample cut into $5 \times 5 \mathrm{~cm}^{2}$ size by using the scissors. Then washed under the water flow for 5-8 minutes by using sterile aquades and dried winds. The maize leaves were soaked in $1 \% \mathrm{NaOCL}$ twice for 1 minute, followed by $70 \%$ alcohol for 1 minute, then washed by using sterile aquades three times for 1 minute, then the leaves were 
dried on the sterile tissue. Furthermore, the leaves were cut by using scissor with $1 \times 1 \mathrm{~cm}^{2}$ size. Endophyte fungi isolation conducted by direct planting technique namely by putting the pieces of dried leaves (5 pieces) and planted to the PDA in petri dish. Then the isolates were incubated at 25$30{ }^{\circ} \mathrm{C}$ for 5 - 7 days or until the fungi growing to fill the petri dish (Muhibuddin et al., 2011).

\section{Helminthosporium turcicum Fungi Pathogen Isolation}

Fungi insulation method in accordance to Sastrahidayat (2011) the infected maize leaves are washed by the water flow. Then inside the LAFC the maize leaf cut into $2 \times 2 \mathrm{~mm}$ wide. The leaf strips were taken by using the tweezers one by one and $10 \%$ Clorox immersed for the surface sterilization for five minutes. The leaf pieces are then removed and immersed in the sterile aquades for three different times to allow the clorox on the surface of the leaf to dissolve in water. Afterwards the pieces of leaves were taken with the sterile tweezers and dried on the sterile tissue. Then the leaves are planted or placed on the PDA medium. Further observed for 5-7 days or until the fungi grows fullfill the petri dish.

\section{Purification}

The purification conducted based on the each fungi colony which considered different such as colony color, colony form.

\section{Observation and Identification}

Purified endophyte fungi isolates which observed then conducted by macroscopically and microscopically in accordance to Muhibuddin et al. (2014). Microscopic observations such as hyphenated or insulated hyphae, hyphae color (dark or transparent hyaline), conidia color (dark or transparent hyaline) and conidia form (round, oval, chain or irregular).

\section{Endophyte Fungi Isolate Screening}

Endophyte Fungi Isolate Screening by using the modified Wilia et al. (2012) method. NK212 maize seed varieties surface was sterilized with $70 \%$ alcohol for 30 seconds, immersed in the $1 \% \mathrm{NaOCL}$ for 2 minutes and rinsed with the sterile aquades for 3 times and planted on PDA medium which has been overgrown with pure isolates of 7-day endophytic fungi.

The observation conducted on the 14th day by the observation indicator if the planted seed were not able to germinate or necrotic arise in sprouts means the fungi is pathogenic and will not used in the further test, whereas the germinated seeds indicate endophyte fungi isolates is not endanger to the plant and potentially as an antagonist agents.

\section{Endophyte Fungi Antagonists Test to Pathogen Fungi}

The test conducted by following the modified Muhibuddin et al. (2014) method. Test by growing the pure cultures of the fungi and each colony fungi endophyte isolate of maize at 7 days age for one cork borer on the petri dish which equipped with the PDA medium. The treatment repeated for 3 times and observed 7 days. Percentage formula of the inhibition (Sharfuddin and Mohanka, 2012) is:

$$
\text { Inhibition Power }=\frac{R 1-R 2}{R 1} \times 100 \%
$$

Explanation :

$\mathrm{R} 1$ = the radius of a pathogen hyphae colony which growing away from the endophyte colony (cm).

$\mathrm{R} 2=$ the radius of a pathogen hyphae colony which growing close to the endophyte colony $(\mathrm{cm})$.

Antagonist Mechanisms Identification by Scaning Electron Microscope (SEM)

Endophyte fungi isolate sample that obtained from the result of antagonist test were taken of one isolate that indicate the antagonist properties which most affected the Helminthosporium turcicum fungi pathogen, then the two fungi isolates were simultaneously prepared between endophyte fungi and pathogen fungi to identify the antagonist mechanisms by using SEM microscopy. 


\section{Data Analysis of Leaf Endophyte Fungi Variety \\ Variety Index $\left(\mathrm{H}^{+}\right)$}

According to (Ludwig and Reynold, 1988) Shannon's variety index aims to obtain a population picture through the number of individuals of each species in a single commodity. The variety index is calculated by the formula:

$$
H^{+}=-\sum_{i=1}^{s}\left(\frac{n i}{N}\right) \operatorname{In}\left(\frac{n i}{N}\right)
$$

Explanation :

$\mathrm{H}^{+}=$Shannon Variety Index

$\mathrm{s}=$ Number of species

$n i=$ Proportion of the number of individuals in the species

$\mathrm{N}=$ The number of individuals of all types

\section{Uniformity Index (E)}

The uniformity index aims to measure the balance of community Uniformity (E) which calculated by the following formula:

$$
\mathrm{E}=\frac{H^{\prime}}{L n s}
$$

Explanation :

$\mathrm{E}=$ Uniformity index

$\mathrm{H}^{\prime}=$ Variety Index

$\mathrm{S}$ The number of genus atau spesies types

\section{Domination Index (C)}

The domination type index is used to determine the dominance of endophyte fungi species in a community. The domination index according to Odum (1994) which calculated by the formula:

Explanation :

$$
C=\sum_{i=1}^{S}\left(\frac{N i}{N}\right)^{2}
$$

$\mathrm{C}=$ Domination Index

$\mathrm{Ni}=$ Number of $1^{\text {st }}$ individual types

$\mathrm{N}=$ Number of individual total

\section{Result and Discussion}

\section{Endophyte Fungi Exploration}

Endophyte fungi be able to isolated of all parts of the plant, as well as the root part, stems, leaves and even flower. In the research of maize plant leaves into the object of the observation and exploration of endophye fungi. Inco et al., (2010) mentioned that the leaves have a changing topography and physical properties, and be able to provide the diverse habitats for othe microorganism communities variety.

Table 1. Isolation result of the maize leaves

$\begin{array}{cccccc}\text { Number } & \text { Isolate Codes } & \text { Variety } & \text { Number } & \text { Isolate Code } & \text { Variety } \\ 1 & \text { DuI1 } & \text { DK95 } & 16 & \text { NuII1 } & \text { NK212 } \\ 2 & \text { DuI2 } & \text { DK95 } & 17 & \text { NuII2 } & \text { NK212 } \\ 3 & \text { DuI3 } & \text { DK95 } & 18 & \text { NuII3 } & \text { NK212 }\end{array}$




\begin{tabular}{cccccc}
4 & DuI4 & DK95 & 19 & NuII4 & NK212 \\
5 & DuI5 & DK95 & 20 & NuIII1 & NK212 \\
6 & DuI6 & DK95 & 21 & NuIII2 & NK212 \\
7 & DuII1 & DK95 & 22 & PuI1 & PERTIWI2 \\
8 & DuII2 & DK95 & 23 & PuII1 & PERTIWI2 \\
9 & DuII3 & DK95 & 24 & PuII2 & PERTIWI2 \\
10 & DuIII1 & DK95 & 25 & PuII3 & PERTIWI2 \\
11 & DuIII2 & DK95 & 26 & PuII4 & PERTIWI2 \\
12 & DuIII3 & DK95 & 27 & PuII5 & PERTIWI2 \\
13 & DuIII4 & DK95 & 28 & PuIII1 & PERTIWI2 \\
14 & NuI1 & NK212 & 29 & PuIII2 & PERTIWI2 \\
15 & NuI2 & NK212 & 30 & PuIII3 & PERTIWI2 \\
\hline
\end{tabular}

Endophyte fungi isolate which has found from this exploration amount to 30 isolates of fungi which were pathogenic and non-pathogenic. Exploration results of the various types and numbers are suspected due to the differences in used varietiy. In accordance to Petrini (1992), mentioned that the abundance and variety of endophye fungi in colonizing the host is influenced by several factors such as differences in plants varieties, sampling sites, rainfall and cultivation aspects.

\section{Endophyte Fungi Screening}

Pathogenic test results of endophytic fungi on the germination of maize seeds indicate the different reactions. From the 30 isolates there are 14 isolates from endophyte fungi which indicate the normal growth of seed growth and only 4 isolates of DuIII4, NuII2, NuII4 and PuIII3 endophyte fungi which indicate the growth of seeds exceeding growth in control treatment.

Pathogenic fungi characteristics in the selection of endophytic fungi such as ungerminated seeds; germinated seeds have necrosis; the seeds are able to germinate and growing but ultimately experience death, while the characteristics of non-pathogenic fungi among other seeds are able to germinate well and roots and maize stem growing well

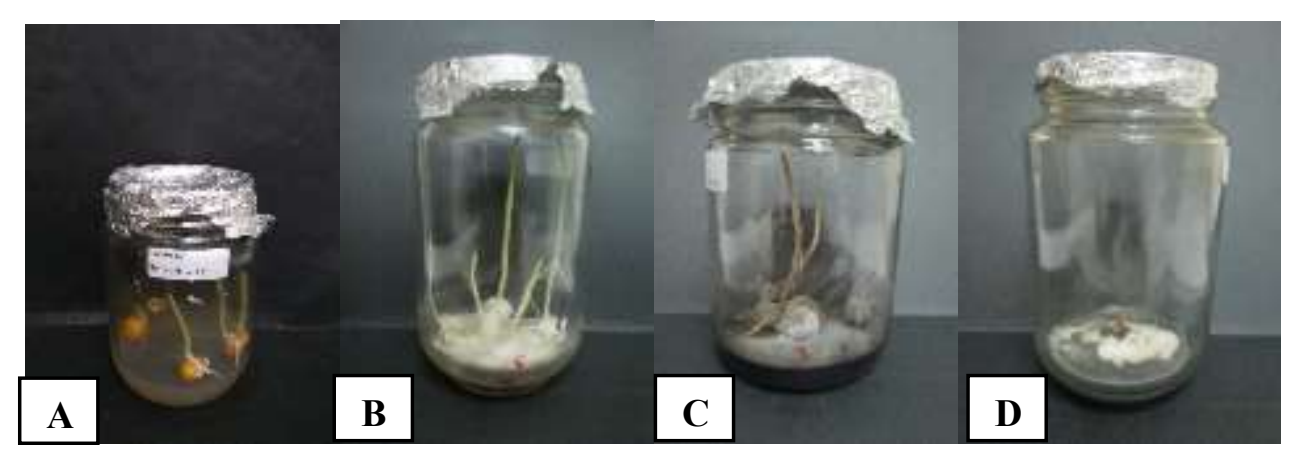


Figure 1. Seed response to endophyte fungi culture : A) Control, B) normal germinated, C) necrotic germinated, D) ungerminated

Based on the pathogenic tests result, most of the endophyte fungi in this research still be able to pursued as pathogens (table 1 and 2). Endophyte fungi derived from the pathogenic fungi which develops into an avirulent pathogen, then evolves into a mutualistic symbiont. Schulz and Boyle (2005) mentioned that the endophyte fungi in their interactions with plants has a role in providing the nutrients and as a protector of the unfavorable external environments and competition with other microorganisms.

Table 2. Endophyte Fungi Screening Result

\begin{tabular}{cccc}
$\begin{array}{c}\text { Isolate } \\
\text { Sources }\end{array}$ & $\begin{array}{c}\text { Amount of } \\
\text { Isolates }\end{array}$ & Pathogenic Fungi & Non-Pathogenic Fungi \\
DK95 & 13 & $6(46.15 \%)$ & $7(53.84 \%)$ \\
NK212 & 8 & $4(50 \%)$ & $4(50 \%)$ \\
PERTIWI 2 & 9 & $6(66.66 \%)$ & $3(33.33 \%)$ \\
Total & 30 & $16(53.33 \%)$ & $14(46.66 \%)$ \\
\hline
\end{tabular}

Endophyte fungi which obtained from the maize crops by DK95 varietiy is the highest of 13 isolates with the $46.15 \%$ percentage of pathogenic fungi and $53.84 \%$ non-pathogenic fungi. Endophytic fungi of PERTIWI 2 varieties were found for 9 isolates with the $66.66 \%$ pathogenic fungi percentage and the percentage of non-pathogenic fungi is $33.33 \%$. Meanwhile the endophyte fungi of NK212 variety which obtained the smallest exploration results of 8 isolates, with the composition of $50 \%$ of pathogenic fungi and $50 \%$ of non-pathogenic fungi.

\section{Endophyte Fungi Antagonists Test to H. turcicum Growth In vitro}

Based on the inhibition power percentage of one and two hsi endophytic fungi candidates presented at (Table 3) has a value that is not significantly different if compared with the control, this indicate that the isolates on the first and second day have not experienced any inhibition mechanism. On the observation the inhibition power percentage of three to seven hsi which has different value compared to control.

Table 3. Isolate inhibition power of the endophyte fungi to Helminthosporium turcicum pathogen fungi isolates

\begin{tabular}{lccccccc} 
Isolate & \multicolumn{7}{c}{ Inhibition power \% (HSI) } \\
Codes & $\mathbf{1}$ & $\mathbf{2}$ & $\mathbf{3}$ & $\mathbf{4}$ & $\mathbf{5}$ & $\mathbf{6}$ & $\mathbf{7}$ \\
& & & & & & & \\
Control & & & & & & & \\
NuI1 & $0.71 \mathrm{a}$ & $0.71 \mathrm{a}$ & $10.71 \mathrm{abcd}$ & $31.15 \mathrm{de}$ & $40.34 \mathrm{~cd}$ & $41.57 \mathrm{def}$ & $42.22 \mathrm{de}$ \\
NuII2 & $2.59 \mathrm{a}$ & $1.55 \mathrm{a}$ & $17.13 \mathrm{cde}$ & $34.69 \mathrm{de}$ & $41.88 \mathrm{~cd}$ & $45.56 \mathrm{ef}$ & $53.33 \mathrm{f}$ \\
\end{tabular}




\begin{tabular}{lccccccc} 
NuII3 & $1.98 \mathrm{a}$ & $1.61 \mathrm{a}$ & $24.03 \mathrm{e}$ & $29.59 \mathrm{~d}$ & $40.84 \mathrm{~cd}$ & $41.57 \mathrm{def}$ & $42.68 \mathrm{de}$ \\
NuII4 & $0.71 \mathrm{a}$ & $1.50 \mathrm{a}$ & $7.48 \mathrm{abcd}$ & $30.53 \mathrm{de}$ & $40.00 \mathrm{~cd}$ & $47.07 \mathrm{f}$ & $51.51 \mathrm{f}$ \\
PuIII1 & $1.98 \mathrm{a}$ & $0.71 \mathrm{a}$ & $15.05 \mathrm{bcde}$ & $27.17 \mathrm{~cd}$ & $39.22 \mathrm{~cd}$ & $40.97 \mathrm{def}$ & $42.34 \mathrm{de}$ \\
PuIII3 & $0.71 \mathrm{a}$ & $0.71 \mathrm{a}$ & $14.51 \mathrm{bcde}$ & $29.52 \mathrm{~d}$ & $44.44 \mathrm{~d}$ & $47.09 \mathrm{f}$ & $48.89 \mathrm{ef}$ \\
DuI3 & $2.15 \mathrm{a}$ & $1.31 \mathrm{a}$ & $6.60 \mathrm{abc}$ & $17.28 \mathrm{bc}$ & $9.14 \mathrm{ab}$ & $13.46 \mathrm{~b}$ & $10.00 \mathrm{~b}$ \\
DuI4 & $0.71 \mathrm{a}$ & $2.18 \mathrm{a}$ & $0.00 \mathrm{a}$ & $2.30 \mathrm{a}$ & $8.19 \mathrm{ab}$ & $12.54 \mathrm{~b}$ & $10.00 \mathrm{~b}$ \\
DuII1 & $3.54 \mathrm{a}$ & $1.85 \mathrm{a}$ & $19.05 \mathrm{de}$ & $17.28 \mathrm{bc}$ & $17.33 \mathrm{~b}$ & $25.06 \mathrm{c}$ & $25.87 \mathrm{c}$ \\
DuII3 & $1.75 \mathrm{a}$ & $1.71 \mathrm{a}$ & $18.70 \mathrm{de}$ & $41.39 \mathrm{e}$ & $46.67 \mathrm{~d}$ & $46.66 \mathrm{f}$ & $42.22 \mathrm{de}$ \\
DuI6 & $0.71 \mathrm{a}$ & $1.55 \mathrm{a}$ & $11.44 \mathrm{abcd}$ & $33.57 \mathrm{de}$ & $42.06 \mathrm{~cd}$ & $42.82 \mathrm{def}$ & $42.82 \mathrm{de}$ \\
DuIII3 & $1.75 \mathrm{a}$ & $1.61 \mathrm{a}$ & $23.99 \mathrm{e}$ & $34.45 \mathrm{de}$ & $37.98 \mathrm{~cd}$ & $47.39 \mathrm{f}$ & $48.11 \mathrm{def}$ \\
DuIII4 & $0.71 \mathrm{a}$ & $3.21 \mathrm{a}$ & $2.08 \mathrm{a}$ & $10.55 \mathrm{ab}$ & $31.54 \mathrm{~cd}$ & $38.57 \mathrm{de}$ & $27.78 \mathrm{c}$ \\
\hline PuII2 & $0.71 \mathrm{a}$ & $0.71 \mathrm{a}$ & $3.52 \mathrm{ab}$ & $16.67 \mathrm{bc}$ & $32.94 \mathrm{c}$ & $35.55 \mathrm{~d}$ & $40.00 \mathrm{~d}$ \\
\hline
\end{tabular}

Number with the same letter in a single column indicate there is no significant difference in the BNJ test $(\alpha=0.05)$.

According to the variety analysis result, the highest inhibition observations of the three HSI to seven in vitro test was demonstrated by the isolates NuII2, NuII4, PuIII3, DuIII3, NuII3 and PuIII1 which had the ability as the antagonist agents to H. turcicum pathogens demonstrated by their consistency in suppress pathogen. While the isolates DuI3, DuI4, DuII1, DuIII4 and PuII2 are the most inhibited isolates of $H$. turcicum growth.

The competition among pathogens and endophyte fungi is the most common mechanism. The isolates of NuII2 and NuII4 are isolates which have the highest competition in fighting for space and nutrition. Other mechanisms demonstrated in this experiment are the mechanisms of competition and antibiosis by the DuIII3 isolate.

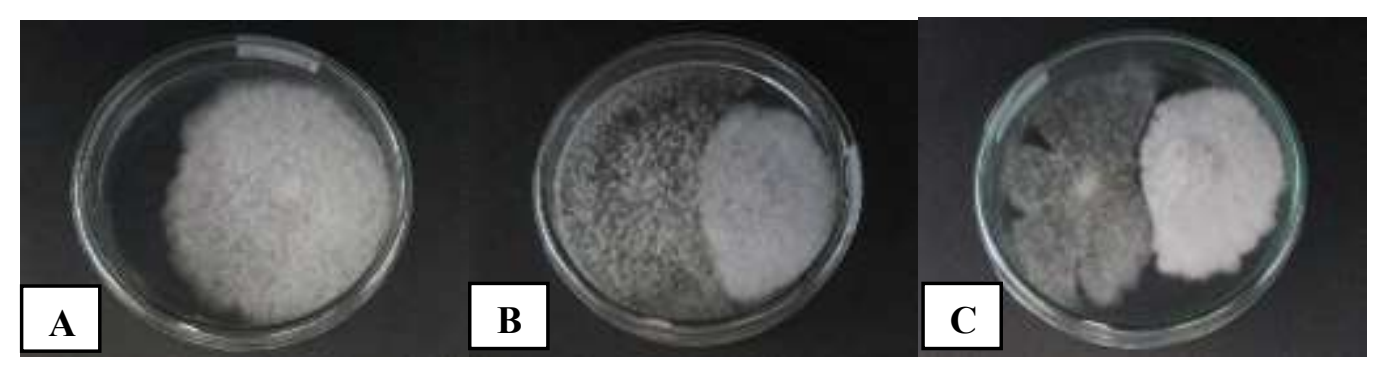

Figure 2. H. turcicum growth in condition: A) without treatment, B) pressured by the competition mechanism, C) pressured by the antibiosis mechanism. 
Endophyte fungi antibiosis is characterized by the presence of pellucid zones at the endophyte encounter with the pathogen. Hallman (2001) mentioned that the antagonist aggravating enzyme must be in direct contact with the pathogen. According to Arnold et al., (2003) the endophyte fungi be able to produce organic volatile compounds such as tetrohydrofuran, 2dimethyl furan, 2-butanol, acipelin (Atmosukarto et al., 2009), EtOAc and n-butanol (Liu et al 2001), as well as pyrrocidines (You et al., 2009).

Meanwhile, in the NuI1, DuII3, DuI6, DuI3, DuI4, DuII1, DuIII4 and PuII2 isolates which have no antibiosis compounds or competition mechanisms in H. turcicum in vitro is alleged to have another activity in controlling plant diseases, such as induced ability plant resistance.

\section{Endophyte Fungi and $\boldsymbol{H}$. Turcicum Fungi Interaction}

The macroscopic observations indicate that almost all endophyte fungi isolate have a competition mechanism, except with the NuI1, DuI3, DuI4, DuII1, DuII3, DuI6, DuIII4 and PuII2 isolate codes

Table 4. Endophyte Fungi with H. turcicum Inhibition Mechanism

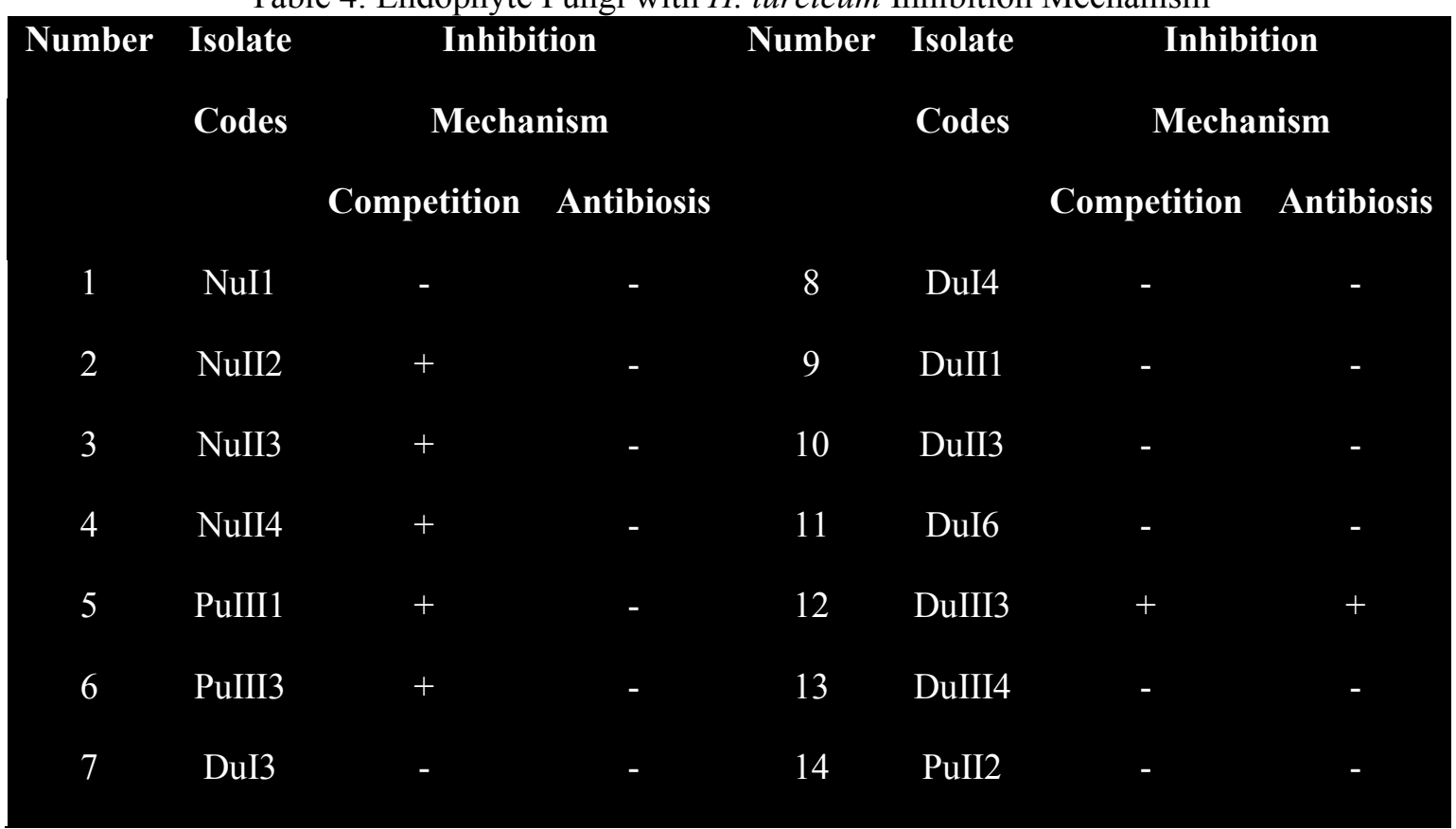

Sign (-) in the antagonist test indicates that the fungi has no such mechanism, Sign $(+)$ in the antagonist test indicates the presence of fungi.

Muhibuddin et al., (2016) mentioned that the mechanism of endophyte fungi protection might be competition, antagonism, microprasite and the induction resistance. The competition mechanism occur on three HSIs, the fungi with the NIIII and NuII4 isolate codes have the growth diameter faster compared to pathogen fungi, its allowing for the competitive mechanism between each of the fungi test. Competition causes the pathogen fungi have no room to grow for their life (Octaviani et al., 2015).

The antibiosis mechanism be able to see from the inhibition zone of in vitro antagonism test results (Figure 3). The presence of the inhibition zone indicates the occurrence of antibiosis mechanism occurs if a biological agent is able to produce metabolite toxic compounds to another organisms thus inhibit growth and kill its host (Kusdiana, 2011). 


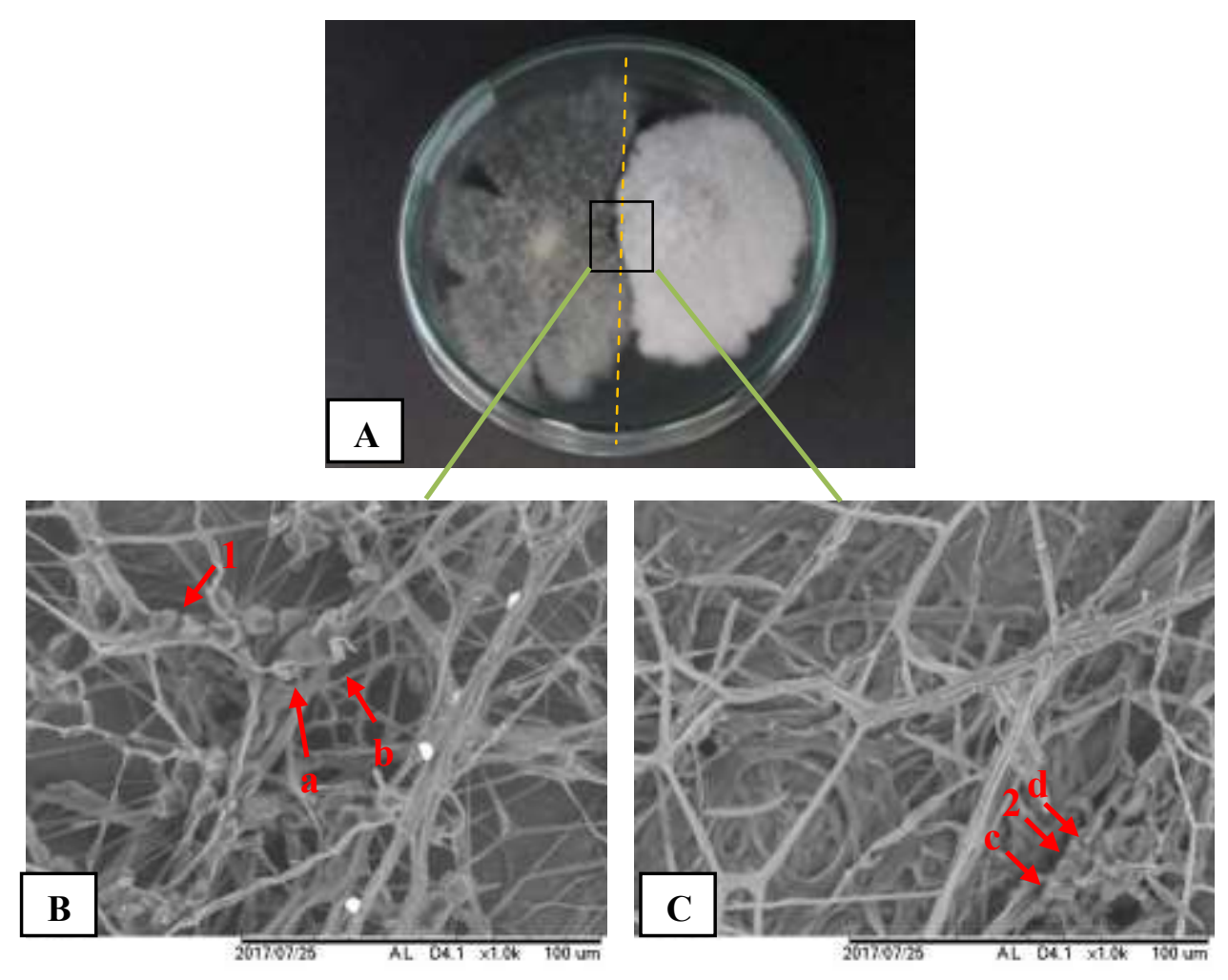

Figure 3. A) Interaction macroscopic between DuIII3 and H. turcicum endophyte fungi, B and C) SEM analysis of DuIII3 and H. turcicum isolate interaction with 1000 times magnification, 1) the pathogenic hyphae is abnormal, 2) Endophyte hyphae bind the pathogen hyphae, a and c) endophyte hyphae, b and d) pathogen hyphae.

Based on the fungi types interaction which represent of two mechanism namely competition and antibiosis indicate in DuIII3 isolate. Interaction observations conducted by using Scanning Electron Microscope (SEM), the interaction between DuIII3 endophyte type and H. turcicum is the distend pathogen hyphae and seemed empty (Figure 3). This is caused by the endophyte fungi seizing the nutrients of the pathogens (nutritional competition) resulting in a change in the inhibited pathogen hyphae. Sunarwati and Yoza (2010) mentioned that the pathogen and antagonist hyphae interactions is characterized by the changing color and pathogen hyphae becomes clear and empty because the cell contents are exploited by the biocontrol agents as nutrients. In addition, endophyte fungi might cause pathogen hyphae, as found by Kurnia et al., (2014). Another form of the interaction between the DuIII3 endophytes and H. turcicum is the hyphae forming a hook around the pathogenic hyphae (Figure 3). Dolakatabadi et al., (2012) mentioned that the endophyte fungi forming a hook around the pathogen hyphae before the penetration or possibly penetrates and enters directly. There is a shape changes in the pathogenic hyphae into a spiral and curved irregular and shortening (Nurzannah et al., 2014).

\section{Endophyte Fungi Variety in Several Varieties Samples}

In this research, the maize plant variety have an influence in the endophytic fungi variety in the nature. There are 30 isolates of the endophyte fungi species were found, 17 isolates identified, 4 unidentified isolates and 9 isolates only issue a sterile hyphae which is difficult to identify. Table 5 indicate that the number of endophyte fungi which colonize the three varieties of maize variety. In accordance to Petrini (1992), who mentioned that the abundance and variety of endophyte fungi in colonizing the host is influenced by several factors such as the differences in crop varieties, sampling sites, rainfall and cultivation aspects. 
Table 5. Calculation Result of Variety, Domination and Uniformity Index

\begin{tabular}{|c|c|c|c|c|c|c|c|}
\hline \multirow[t]{2}{*}{ Number } & \multirow[t]{2}{*}{ Variety } & \multicolumn{3}{|c|}{ Index Value } & \multirow{2}{*}{$\sum_{\text {Genus }}$} & \multirow{2}{*}{$\sum_{\text {Spesies }}^{\sum}$} & \multirow{2}{*}{$\sum_{\text {Coloni }}^{\sum}$} \\
\hline & & $\mathrm{H}^{\prime}$ & $\mathrm{C}$ & $\mathrm{E}$ & & & \\
\hline 1 & DK95 & $\begin{array}{c}2.351 \\
\text { (Medium) }\end{array}$ & $\begin{array}{l}0.100 \\
\text { (Low) }\end{array}$ & $\begin{array}{c}0.980 \\
\text { (High) }\end{array}$ & 11 & 11 & 13 \\
\hline 2 & NK212 & $\begin{array}{c}1.754 \\
\text { (Medium) }\end{array}$ & $\begin{array}{l}0.250 \\
\text { (Low) }\end{array}$ & $\begin{array}{c}0.928 \\
\text { (High) }\end{array}$ & 5 & 5 & 8 \\
\hline 3 & Pertiwi 2 & $\begin{array}{c}2.043 \\
\text { (Medium) }\end{array}$ & $\begin{array}{l}0.133 \\
\text { (Low) }\end{array}$ & $\begin{array}{c}0.979 \\
\text { (High) }\end{array}$ & 8 & 8 & 9 \\
\hline
\end{tabular}

\section{Endophyte Fungi Leaves Variety Data Analysis}

Variety index calculation result be able to see in the (table 5). Variety index in the DK95 variety sample was obtained 2,351 result, NK212 variety was obtained 1.754 result and samples with the Pertiwi 2 variety was obtained 2,043. According to Brower and Zar (1997) mentioned that the $<1$ value, which mean has low variety criteria, $1-3$ value means the value of medium variety, and $>3$ means the high variety criteria.

Domination index calculation be able to see in the (table 5). Domination index in the sampling with DK95 variety is obtained 0100 result, on the sampling with NK212 variety is obtained 0.250 result and in the PERTIWI 2 variety sampling is obtained 0133 result. Hamsiah (2006) mentioned that if the domination index value between $0.00-0.050$ is classified to the low criteria, between $0.50-075$ is classified to the medium criteria and between $0.75-1.00$ is classified to the high criteria. In this research, the number of domination sampling with the NK212 variety namely 0.250 indicate the appearance of domination among genus. The dominated fungi is Curvularia sp.

Uniformity index calculations result be able to see in the (table 5). Uniformity index on sampling with the DK95 variety is obtained 0.980 result, on sampling with the NK212 variety is obtained 0.928 result, meanwhile on sampling with the PERTIWI 2 variety is obtained 0.979 result. Brower dan Zar (1997) statement that if the variety index value ranges from $0.00-0.50$ is classified to the low uniformity criteria with the pressured community, the uniformity index value between $0.50-0.75$ is classified to the medium uniformity criteria with the unstable community, while the uniformity index value between $0.75-1.00$ is classified to the high uniformity criteria with the stable communities.

\section{Conclusion}

The isolated endophyte fungi is 30 isolates, consisting of $53.33 \%$ pathogenic and $46.66 \%$ non-pathogenic. Six isolates of the tested 14 endophytic fungi indicate the H. turcicum growth inhibition in vitro and the most inhibition mechanism happened is between pathogen and endophyte fungi competition. From the identified 30 isolates up to the genus level is Colletotrichum sp, Fusarium sp, Curvularia sp, Acremonium sp and Paecilomyces sp, while other endophyte fungi only found sterile hyphae so it is difficult to be identified up to the genus level.

\section{Acknowledgments}

Praise and thank of the author - Alhamdulillah pray to Allah SWT for His love and guidance so the author could complete this research. The author acknowledge to Prof. Dr. Ir. Ika Rochdjatun Sastrahidayat, as the first thesis supervisor and Dr. Anton Muhibuddin, SP., MP., as the second thesis supervisor, gratitude to the suggests, guidance and advice which given during this research results preparation. Acknowledgment also presented to the beloved parents and brother and sister who always give encouragement, support and prayer. 


\section{REFERENCES}

Arnold AE, Mejia LC, Kyllo D, Rojas EI, Maynard Z, Robbins N, Herre EA. 2003. Fungal endophytes limit pathogen demage in a tropical tree. PNAS. 100:15649-15654.

Atmosukarto I, Castillo U, Hess WM, Sears J, Strobel G. 2005. Isolation and characterization of Muscodor albus I-4.3s, a volatile antibiotic producing fungus. Plant Sci. 169:854-861.

Bakhri, S, 2007. Budidaya Jagung Dengan Konsep Pengelolaan Tanaman Terpadu (PTT). Balai Pengkajian Teknologi Pertanian (BTTP), Sulawesi Tengah.

Badan Pusat Statistik. 2012. Data Strategis Badan Pusat Statistik. Katalog BPS: 1103003. Badan Pusat Statistik. Jakarta

Brower, J.E, dan J.H. zar,. 1997. Field and Laboratory Methods for General Ecology. WMJ. Brown Company Publisher. Dubuque. Lowa. Hal. 94.

Dolakatabadi, H.K., E.M. Goltapeh, N. Mohammadi, M. Rabiey, N. Rohani, and Varma. 2012. Biocontrol potential of root endophytic fungi dan Trichoderma species againts Fusarium wilt of lentil under in vitro and greenhouse condition. Agriculture Science Technology 14:407420.

Hallmann J. 2001. Plant interaction with endophytic bacteria. Di dalam: Jeger MJ, Spence NJ, Editors. Biotic Interaction in Plant-Pathogen Associations. Wallingford (US): CABI. hlm 87-119.

Hamsiah, 2006. Potensi Jenis Kekarangan Yang Berasosiasi Dengan Padang Lamun di Pualau Pannikiang Kabupaten Barru. Fakultas Perikanan dan Ilmu Kelautan UMI. Jurnal Protein. Makasar. Vol. 13 No.2

Kusdiana APJ. 2011. Eksplorasi dan identifikasi cendawan antagonis terhadap Rigidoporus lignosus penyebab jamur akar putih pada karet [skripsi]. Bogor (ID): Fakultas Pertanian, Institut Pertanian Bogor.

Kurnia, A.T., M. I. Pinem, dan S. Oemry. 2014. Penggunaan jamur endofit untuk mengendalikan Fusarium oxysforum f.sp. capsici dan Alternaria solani secara in vitro. Jurnal online Agroteknologi 2(4):1596-1606.

Liu CH, Zou WX, Lu H, Tan RX. 2001. Antifungal activity of Artemisia annua endophyte cultures against phytopathogenic fungi. J Biotechnol. 88:277282.

Ludwig, J. A. dan J.F. Reynold. 1988. Statistical Ecology : A Primer on Methods and Computing. John Wiley and Sons Inc.Canada.

Muhibuddin, A. L., Addina, A. L. Abadi dan A. Ahmad. 2011. Biodiversity of Soil Fungi On Integgrated Pest Management Framing System. Agrivita Vol 33 No.22 : 111-118.

Muhibuddin, A. R.H. Sofiana, L. Sulistyowati. 2015. Eksplorasi Jamur Endofit dan Khamir Pada Tanaman Cengkeh (Syzygium aromaticum) Serta Uji Potensi Antagonisnya Terhadap Jamur Akar Putih (Rigidoporus microporus). Jurnal HPT Volume 3 Nomer 1.

Muhibuddin, A. S.A. Zuhria, S. Djauhari. 2016. Exploration and Antagonistic Test of Endophytic Fungi from Soybean (Glycine max L. Merr) With Different Resistance to Sclerotium rolfsi. J.Exp.Life Sci. Vol. 6 No. 2.

Muhibuddin, A. D. Wulandari, L. Sulistyowati. 2014. Keanekaragaman Jamur Endofit Pada Tanaman Tomat (Lycopersicum esculentum Mill.) dan Kemampuan Antagonisnya Terhadap Phytophtora infestans. Jurnal HPT Volume 2 Nomer 1.

Nurzannah, S.E. Lisnawita, dan D. Bakti. 2014. Potensi jamur endofit asal cabai sebagai agens hayati untuk mengendalikan layu Fusarium (Fusarium oxysforum) pada cabai dan interaksinya. Jurnal Online Agroekoteknologi 2(3): 1230-1238.

Octaviani EA, Achmad, Herliyana EN. 2015. Potensi Trichoderma harzianum dan Gliocladium Sp. sebagai agens hayati terhadap Botryodiplodia sp. penyebab penyakit mati pucuk pada jabon (Anthocephalus cadamba (Roxb.) miq). Jurnal Silvikultur Tropika. vol 06(1):27-32.

Odum, E.P. 1994. Dasar-dasar Ekologi, $3^{\text {rd }}$ Ed. Samingar, T. (Transl). Gadjah Mada University Press. Yogyakarta. 
Ogliri, J.B., M.A. Guimaraes, I.O. Geraldi and L.E.A Camargo 2005. New Resistence Genes in the Zea mays Exserohilum turcicum pathosystem Genet. Mol. Biol. Vol. 28 no.3 Sao Paulo.

Petrini,O., T.N Sieber, L Toti dan O. Viret. 1992. Ecology Metabolite Production and Substrate Ultilization in Endophytic Fungi. Natural Toxins (1) : 185-196

Petrini O. 1992. Fungal endhophytes of tree leaves. di dalam : Andrews JH, Hirano SS, editor. Microbial Ecology of Leaves. Berlin : Springer Verlag. hlm : 179 - 196

Roliyah, Y. 2000. Laporan Perekembangan Penyakit Hawar Daun pada Tanaman Jagung di Provinsi Sumatra Utara. Balai Proteksi Tanaman Pangan dan Hortikultura. Medan. Hal 21.

Sastrahidayat, I.R. 2011. Mikologi (Ilmu Jamur). Malang. UB Press

Schulz B, Boyle C. 2005. The endophytic continuum. Mycologia 109(6):661-686.

Sharfuddin, C and Mohanka, R. 2012. In vitro Antagonism of Indigenous Trichoderma Isolates Against Phytopathogen Causing Wilt of Lentil. Int. J. Life Sci. Pharm. Res. 2(3). L195L202.

Sunarwati, D. dan R. Yoza, 2010. Kemampuan Trichoderma dan Penicillium dalam menghambat pertumbuhan cendawan penyebab penyakit busuk akar durian (Phytophthora palmivora) secara in vitro. Prosiding Seminar Nasional Program dan Strategi Pengembangan Buah Nusantara. Solok 10 Nopember 2010. http://balitbu.litbang.pertanian.go.id [30 Desember 2015]: 176-189.

Sudantha, I. M dan A. L. Abadi. 2006. Uji Efektivitas Beberapa Isolat Jamur Endofit Antagonistik dalam Meningkatkan Ketahanan Induksi Beberapa Klon Vanili Terhadap Penyakit Busuk Batang. Universitas Mataram. Mataram.

Wilia W, Hayati I, Ristiyadi D. 2012. Eksplorasi Cendawan Endofit Dari Tanaman Padi Sebagai Agen Pemacu Pertumbuhan Tanaman. Agroekoteknologi 1(4): 73-79

Wilson, D. 1995. Endophyte the evolution of a term, and clarification of its use and definition. Oikos. 73.274-276.

You F, Han T, Wu JZ, Huang BK, Qin LP. 2009. Antifungal secondary metabolites 